\title{
Working
}

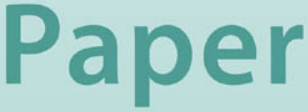




\section{Tax Revenue Response to the Business Cycle}

Cemile Sancak, Ricardo Velloso, and

Jing Xing 


\title{
IMF Working Paper
}

\section{Tax Revenue Response to the Business Cycle ${ }^{1}$}

\author{
Prepared by Cemile Sancak, Ricardo Velloso, and Jing Xing
}

Authorized for distribution by Paolo Mauro

March 2010

\begin{abstract}
This Working Paper should not be reported as representing the views of the IMF. The views expressed in this Working Paper are those of the author(s) and do not necessarily represent those of the IMF or IMF policy. Working Papers describe research in progress by the author(s) and are published to elicit comments and to further debate.
\end{abstract}

This paper examines tax revenue during the business cycle by estimating the relationship between tax revenue efficiency and the output gap. We find a positive and significant relationship between these variables; results are consistent for quarterly and annual data, and across advanced and developing economies. We also find that a worsening (improvement) in the VAT C-efficiency is driven by shifts in consumption patterns and changes in tax evasion during contractions (expansions). A key implication is that, particularly during major economic booms and downturns, policy makers should look beyond simple, long-run revenue elasticities and incorporate into their analysis the effects of the economic cycle on tax revenue efficiency.

JEL Classification Numbers: E32, H2, H21, H26

Keywords: tax revenue forecasting, business cycle, tax revenue efficiency, C-efficiency, VAT elasticity

Author’s E-Mail Address: csancak@imf.org, rvelloso@imf.org, jing.xing@nuffield.ox.ac.uk

\footnotetext{
${ }^{1} \mathrm{We}$ are thankful for the useful comments from participants in the FAD/F2 informal seminar held in August 2009 and the FAD internal seminar held in January 2010, as well as the encouragement and suggestions from John Brondolo, Carlo Cottarelli, James Daniel, Mark De Broeck, Mick Keen, Thornton Matheson, Paolo Mauro, and John Norregaard. Sukhmani Bedi and Junhyung Park provided invaluable research assistance, and Liz Estabrook and Katia Chen excellent editorial help.
} 


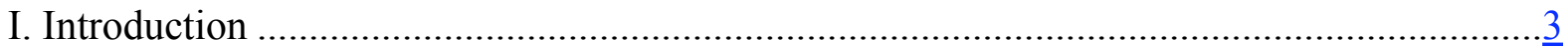

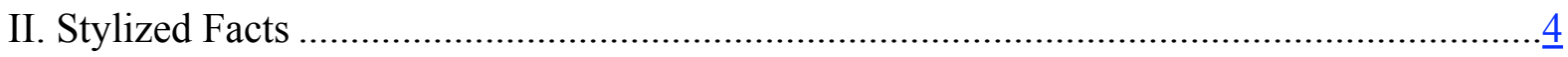

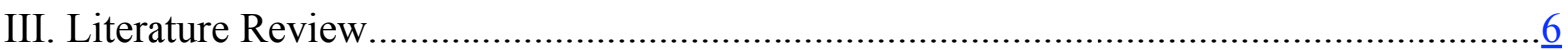

IV. Data

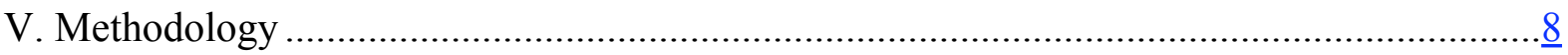

A Model for Tax Revenue Efficiency .......................................................... 8

A Model for Tax Revenue Elasticity ……………………………………......

VI. Estimation Results for VAT C-efficiency ……………................................................

VII. Estimation Results for PIT and SSC Efficiency .......................................................

VIII. Estimation Results for VAT Revenue Elasticity.......................................................

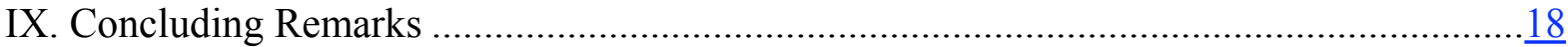




\section{INTRODUCTION}

Long-run revenue elasticities do not hold well during output contractions and expansions. During recessions, tax revenue collapses more sharply than does the tax base. Conversely, tax revenue rises more strongly than does the tax base during economic booms. As the long-run revenue elasticity is commonly used in revenue projections, there is thus a tendency to overestimate revenue during contractions, and vice-versa. The recent global economic crisis has confirmed this tendency, which has been particularly pronounced in the countries most affected by the crisis. ${ }^{2}$ Improvements in revenue forecasting would help governments have a better understanding of the likely evolution of fiscal balances and financing needs during the business cycle, thereby minimizing the potential need for abrupt corrective measures.

To our knowledge, there has been no systematic attempt to examine the response of tax revenue to the business cycle. This paper aims to address this issue by estimating the relationship between tax revenue efficiency ${ }^{3}$ and the output gap, ${ }^{4}$ as well as the response of tax revenue collections to changes in the tax base and output gap. We draw on uniquely detailed databases for a broad set of advanced and developing economies. The paper examines primarily the value added tax (VAT), and complements that analysis with an examination of the personal income tax (PIT) and social security contributions (SSC), which altogether account for a large share of tax revenue in many economies.

In the case of the VAT, we find that a one percentage point increase in the output gap corresponds to a $1 \frac{1 / 4}{4}$ percentage point increase in the efficiency of this tax or, equivalently, to a $13 / 4$ percent increase in VAT collections. The results reported in the paper are consistent for quarterly and annual data, and across advanced and developing economies.

We also find that a worsening (improvement) in VAT C-efficiency is driven by shifts in consumption patterns toward goods and services with lower (higher) VAT rates, and increases (decreases) in tax evasion during contractions (expansions). Indeed, shifts in consumption patterns and tax evasion appear to be the main channels through which the output gap has an

\footnotetext{
${ }^{2}$ For example, Eble, Sancak, and Velloso (2009) show that revenue forecasts prepared in the last quarter of 2008 turned out to be too optimistic for several European countries that experienced sharp recessions and balance of payment pressures and, as a result, requested IMF financial support. Deviations were explained mainly by: an optimistic "tax base" growth forecast; a breakdown of the expected relationship between the proxy tax base (e.g., nominal GDP) and the "true" tax base due to changes in the composition of GDP; and a breakdown of the relationship between the "true" tax base and revenue collections due to increases in tax noncompliance, the use of loss carry forward (or backward) provisions, tax refunds, etc.

${ }^{3}$ We define tax revenue efficiency as the share of tax revenues in the tax base, normalized by the standard tax rate: tax revenue efficiency ratio $=($ tax revenue/tax base $) /$ standard tax rate*100. In the case of the VAT, this is commonly referred to as C-efficiency, where $\mathrm{C}$ stands for consumption (the tax base). Ebrill and others (2001) explain the advantages of using the tax base - rather than GDP - to estimate the tax revenue efficiency ratio.

${ }^{4}$ The output gap is defined as the deviation of actual real GDP from the HP-filter-derived potential real GDP. For the HP filter, the end point is taken as 2014, when countries are assumed to grow along trend growth. A positive gap means that actual real GDP is above potential.
} 
impact on VAT C-efficiency. A closer examination of the determinants of tax evasion reveals that VAT C-efficiency is positively correlated with stronger institutional underpinnings of the revenue administration, and negatively correlated with the overall tax burden in the economy.

The paper is structured as follows. The next section presents stylized facts on the behavior of the tax revenue efficiency during the business cycle. Section III reviews the (limited) empirical literature in this area. Section IV describes the data. Section V outlines the methodology. Section VI presents the results for VAT C-efficiency, and section VII for PIT and SSC efficiency. Section VIII reports the estimation results for VAT revenue elasticity. The last section discusses policy implications of the key findings and concludes the paper.

\section{STYLIZED FACTS}

An examination of the growth rate of tax collections and of the growth rate of their respective bases reveals that, during the business cycle, these variables are correlated. It also reveals that changes in the former tend to be more pronounced than in the latter.

For example, the growth rate of VAT collections in the three Baltic countries (Estonia, Latvia, and Lithuania), which were among the hardest hit by the recent global economic crisis, ${ }^{5}$ was lower than the growth rate of private consumption in each of these countries during the sharp contractions of 2008-09 (Figure 1a). Similarly, the growth rate of VAT collections was higher than that of private consumption in each of the three Baltic countries when they experienced sharp expansions during 2005-07 (Figure 1b).

\footnotetext{
${ }^{5}$ Real GDP contracted by $213 / 4$ percent in Latvia and 17 percent in Estonia over 2008-09, and by 15 percent in Lithuania in 2009. This followed sharp expansions over 2005-07, when real GDP increased by $361 / 2$ percent in Latvia, 29 percent in Estonia, and 27\%/4 percent in Lithuania.
} 
Figure 1a. Average Annual Growth Rates of VAT and Consumption 2008-09

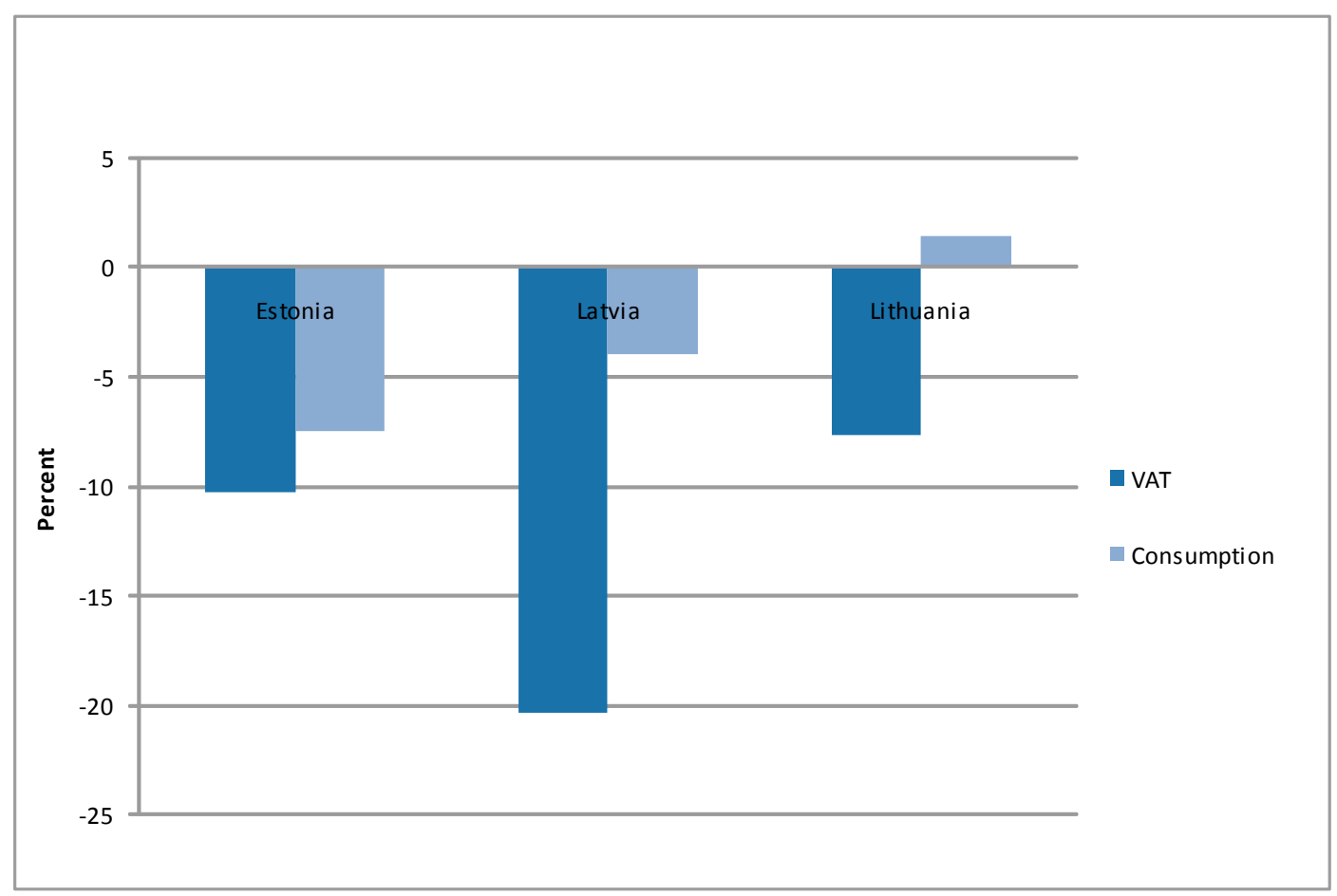

1/ For 2009, the first six months of the year were compared to the first six months of the previous year. Sources: Eurostat and IMF staff estimates.

Figure 1b. Average Annual Growth Rates of VAT and Consumption 2005-07

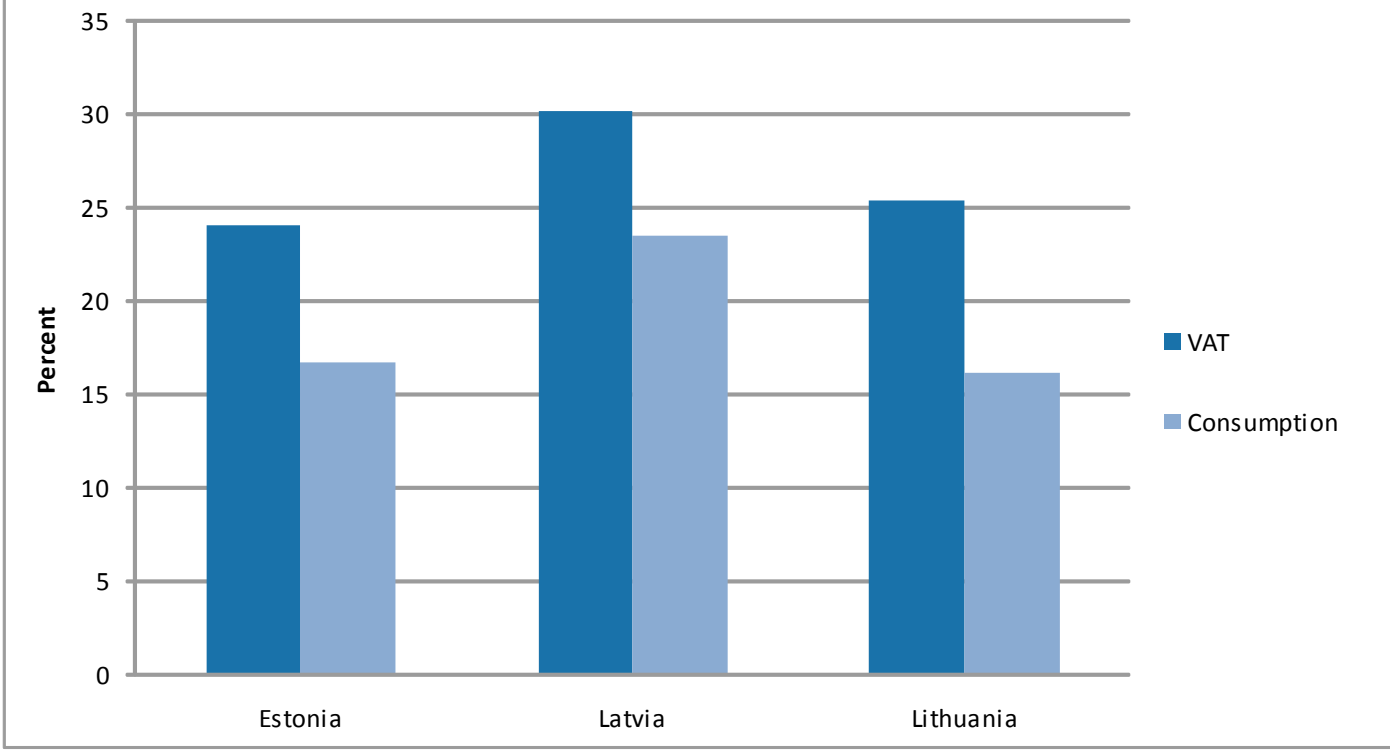

CInternational Monetary Fund. Not for Redistribution 
A similar pattern emerges for longer periods and a broader set of countries. For EU countries, for example, a preliminary analysis of the relationship between VAT C-efficiency and the output gap shows a positive correlation between the two variables over 1995-2008 (Figure 2). ${ }^{6}$

Figure 2. VAT C-efficiency and Output Gap

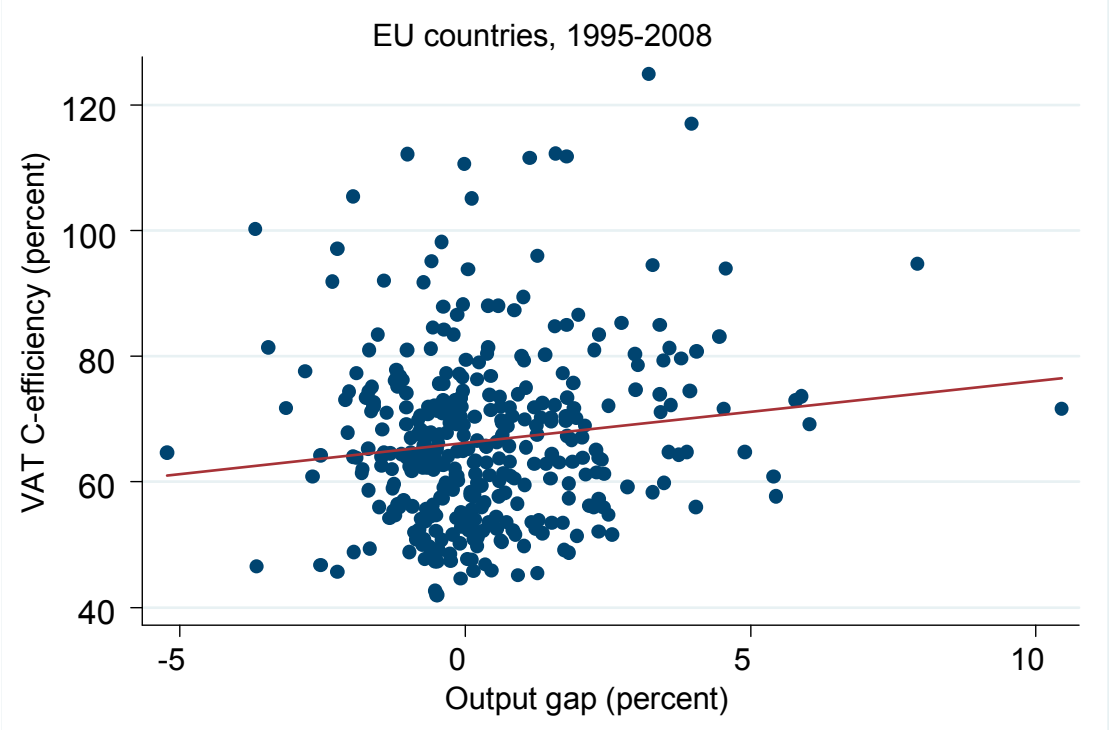

Sources: Eurostat and IMF staff estimates.

Notes: There are 405 observations. The output gap coefficient is 0.9 , and $p$-value is less than 0.01 . The association remains significant at the conventional levels when using robust estimation techniques that drop influential observations (Table 2 presents estimation results).

\section{LITERATURE REVIEW}

Although the relationship between tax revenue efficiency and the business cycle has not previously been analyzed, some studies have explored the long-term, structural determinants of the efficiency of tax collections, and a few studies have looked into the relationship between tax compliance and the business cycle.

Agha and Haughton (1996) provide an early cross-country empirical analysis of the long-term determinants of VAT C-efficiency. Using 1987 data from 17 OECD countries, they find that VAT C-efficiency improves with a lower standard rate, fewer non-zero rates, longer VAT implementation periods, and higher spending on tax revenue administration. In a more recent cross-section study, De Mello (2009) uses 2003 data from 42 countries, including mainly OECD and a few non-OECD countries. His results confirm that VAT C-efficiency increases with a lower standard rate, and suggest that VAT C-efficiency rises when the share of administrative costs in tax revenue is lower, indicating a more effective tax administration, and when a country has better regulatory quality, rule of law, and government effectiveness.

\footnotetext{
${ }^{6}$ A similar result is obtained for 84 advanced and developing economies over 1995-2008.
} 
A panel data analysis on the determinants of VAT C-efficiency, using data from 44 countries over 1970-1999, is found in Aizenman and Jinjarak (2008). ${ }^{7}$ Their results highlight the influence of political factors (such as the durability of the political regime and ease and fluidity of political participation) over VAT C-efficiency. In addition, urbanization, trade openness, and the share of agriculture in the economy are also found to be important explanatory factors.

A few studies have explored the relationship between tax compliance and the business cycle. Plumley (1996) finds that income tax compliance is negatively linked to the unemployment rate, and Cai and Liu (2009) show that corporate income tax (CIT) compliance is linked to firms' credit constraints.

Building on these efforts, our study attempts to address the issue of tax revenue efficiency changes during the business cycle more explicitly, drawing on uniquely detailed databases covering more recent years. These databases allow us to explore the annual and quarterly behavior of tax collections, particularly VAT collections, for a large group of advanced and developing economies. Our study is thus an attempt to enhance the understanding of tax revenue efficiency and its short-term determinants.

\section{DATA}

We use three data sets in the estimations. The first consists of annual data from 1995 to 2008 for $32 \mathrm{EU}$ countries, and the second of annual data for the same period for 84 advanced and developing economies. The third data set consists of quarterly data from the first quarter of 1999 to the first quarter of 2009 for 37 advanced and developing economies. The list of countries in each data set is reported in the Appendix.

Quarterly and annual VAT, PIT, and SSC data for the EU countries are obtained from Eurostat's general government surveys. Tax revenue data for countries outside the EU are from the IMF's Government Finance Statistics (GFS) and individual country data collected by IMF staff. VAT standard rates are drawn from a database of the IMF's Fiscal Affairs Department, while PIT and SSC rates are from Eurostat. GDP, private consumption, and wages and salaries are drawn from the IMF's World Economic Outlook (WEO) database. The qualitative indicator on the control of tax evasion is from the IMD's World Competitiveness Online, and the qualitative "law and order" indicator is from the International Country Risk Guide. The share of necessity goods in total consumption is from Eurostat.

\footnotetext{
${ }^{7}$ In their study, the VAT standard rate of the year 2003 was used to construct VAT C-efficiency for the entire period of 1970-1999. In our study, the annual VAT standard rate of each country is used in the calculation of VAT C-efficiency.
} 


\section{Methodology}

\section{A Model for Tax Revenue Efficiency}

We estimate the following fixed effects regression model using panel data on advanced and developing economies:

$$
\text { taxefficiency }_{i t}=\alpha_{i}+\beta_{1} \text { gap }_{i t}+\varepsilon_{i t}
$$

where taxefficiency ${ }_{i t}$ stands for the tax revenue efficiency ratio, ${ }^{8}$ gap $_{i t}$ stands for the output gap, $\alpha_{i}$ are country-specific intercepts, and $\varepsilon_{i t}$ is the error term. ${ }^{9}{ }^{10}$

In some specifications, we explore whether the association between tax revenue and the output gap is stronger in good times or bad times. We define good (bad) times as periods when the actual real GDP growth rate is above (below) the potential real GDP growth rate. A positive and significant correlation between tax revenue efficiency and the output gap raises the question of whether a decline in tax revenue efficiency during bad times would be fully reversed during good times. In other words, is the impact of bad times on tax revenue efficiency permanent? The paper tries to answer this question by interacting a "bad times" dummy variable with the output gap. ${ }^{11}$

In some estimates, we test whether changes in VAT C-efficiency during the business cycle are more pronounced in developing than in advanced economies by interacting an "advanced economy" dummy variable with the output gap.

Next, we introduce to the simple model described in equation 1 additional explanatory variables $\left(X_{i t}\right)$ that may affect tax revenue efficiency and provide channels through which the output gap variable has an impact on VAT C-efficiency:

\footnotetext{
${ }^{8}$ In practice, the tax revenue efficiency ratio can be below or above 100 percent. In the case of the VAT, for example, zero-rating or exemptions would lower the efficiency ratio below 100 percent, while breaks in the VAT chain resulting in the taxation of both final consumption and intermediate goods could increase the efficiency ratio above 100 percent. As the focus of this paper is not on the level of the tax revenue efficiency ratio or structural differences across countries but rather on changes in efficiency during the business cycle, this issue is immaterial.

${ }^{9}$ The relationship between VAT C-efficiency and the output gap is found to be linear for annual data and very close to linear for quarterly data.

${ }^{10}$ While the model controls for changes in tax rates, it does not control for other changes in tax policy, such as lower/preferential rates or exemptions.

${ }^{11}$ The output gap is based on the level of actual real GDP relative to that of potential real GDP, whereas the dummy variable is based on the growth rate of actual real GDP relative to that of potential real GDP. The "bad times" dummy variable is thus intended to capture both slowdown and recession periods that move output toward or deeper below potential output.
} 


$$
\text { taxefficiency } y_{i t}=\alpha_{i}+\beta_{1} \text { gap }_{i t}+\beta_{2} X_{i t}+\varepsilon_{i t} .
$$

The first $X$ variable, the share of necessity goods in total consumption, is a proxy for shifts in consumption patterns. As incomes decline, the share in the total of consumption of necessity goods - usually zero-rated or taxed at lower rates than the standard rate-increases, while the share of luxury goods decreases. Another $X$ variable, the ability to control tax evasion, is a proxy for tax compliance. During downturns, compliance may suffer as, for example, creditconstrained taxpayers fail to pay their taxes to help finance themselves. ${ }^{12} \mathrm{We}$ also test for possible determinants of tax evasion, such as the legal system and its observance, and the level of the tax burden. ${ }^{13}$

\section{A Model for Tax Revenue Elasticity}

While the tax revenue response to the business cycle is presented in a simple conceptual manner in the models above, many practitioners use tax revenue elasticities for revenue forecasting. To express the analysis in these terms, we also explicitly estimate VAT revenue elasticities by moving the left-hand side variables in the denominator of the tax revenue efficiency ratio in equation (1) to the right-hand side as follows:

$$
\text { taxrevenue }_{i t}=\alpha_{i}+\beta_{1} \text { taxbase }_{i t}+\beta_{2} \text { taxrate }_{i t}+\beta_{3} \text { gap }_{i t}+\varepsilon_{i t},
$$

where taxrate $_{i t}$ is the standard rate.

\section{ESTIMATION RESULTS FOR VAT C-EFFICIENCY}

We first estimate equation (1) using quarterly data (Table 1$) \cdot{ }^{14}$ Column 1 shows that the estimated output gap coefficient is positive and significant at the 1 percent level. A one percentage point increase in the output gap in one quarter is associated with an increase in VAT $\mathrm{C}$-efficiency by 0.29 percentage point. This key result of our paper is robust to changes in specifications, as shown below.

The observations are then split into "bad times" and "good times" sub-samples, with the "bad times" dummy variable equal to 1 for periods when the actual real GDP growth rate is below

\footnotetext{
${ }^{12}$ Brondolo (2009) examines challenges and policy options for preserving tax compliance during an economic crisis.

${ }^{13}$ There may be other explanatory factors. For example, requests for VAT refunds have been observed to increase during downturns in some countries. Provisions for tax payment in installments and for loss carry forward and backward may also contribute to deviations from long-run elasticities during the business cycle.

${ }^{14}$ For quarterly data, private consumption in the previous quarter was used as the tax base for the VAT in the current quarter, because many countries in the sample exhibit a lagged pattern for VAT collections.
} 
potential. ${ }^{15}$ The results reported in columns 2 and 3 show that the positive and significant relationship between VAT C-efficiency and the output gap holds for both sub-samples. ${ }^{16}$

Table 1: Estimation Results: Good, bad times, Quarterly Data

Dependent variable: VAT C-efficiency

\begin{tabular}{|c|c|c|c|c|}
\hline VARIABLES & $\begin{array}{l}\text { Full sample 1/ } \\
\text { (1) }\end{array}$ & $\begin{array}{l}\text { Bad times } \\
(2)\end{array}$ & $\begin{array}{l}\text { Good times } \\
\text { (3) }\end{array}$ & $\begin{array}{l}\text { Interacted } \\
(4)\end{array}$ \\
\hline Gap & $\begin{array}{l}0.286 * * * \\
(0.061)\end{array}$ & $\begin{array}{l}0.332 * * * \\
(0.085)\end{array}$ & $\begin{array}{l}0.184^{*} \\
(0.100)\end{array}$ & $\begin{array}{l}0.190 * * \\
(0.096)\end{array}$ \\
\hline Bad times & & & & $\begin{array}{l}-1.874 * * * \\
(0.555)\end{array}$ \\
\hline Bad times*Gap & & & & $\begin{array}{l}0.145 \\
(0.129)\end{array}$ \\
\hline Constant & $\begin{array}{l}69.279^{* * * *} \\
(0.281)\end{array}$ & $\begin{array}{l}68.881 * * * \\
(0.387)\end{array}$ & $\begin{array}{l}69.663^{* * *} \\
(0.400)\end{array}$ & $\begin{array}{l}70.107 * * * \\
(0.394)\end{array}$ \\
\hline Observations & 1117 & 454 & 661 & 1115 \\
\hline R-squared & 0.017 & 0.038 & 0.005 & 0.027 \\
\hline Number of countries & 37 & 36 & 37 & 37 \\
\hline
\end{tabular}

$1 /$ Countries in the sample are listed in list A in the Appendix.

Notes: Robust standard errors in parentheses; ${ }^{* * *} \mathrm{p}<0.01,{ }^{* *} \mathrm{p}<0.05,{ }^{*} \mathrm{p}<0.1$

In a further variant, the model includes the "bad times" dummy variable and an interaction term between this variable and the output gap (column 4). Under this specification, the constant term is average VAT C-efficiency during good times, assuming the economy is growing along its trend growth. The "bad times" dummy coefficient will capture any difference in the constant term between bad and good times. The output gap coefficient is the slope of VAT C-efficiency with respect to the output gap during good times, and the interaction term coefficient is the difference of this slope between bad and good times.

Column 4 shows that VAT C-efficiency tends to be lower on average when the economy is growing below trend, as the estimated "bad times" dummy variable coefficient is negative and significant. However, in terms of the slope, there is no significant difference between good and

\footnotetext{
${ }^{15}$ Similar results obtain when bad times are defined as periods when the actual real GDP growth was at least one percentage point lower than real potential GDP growth. The sample size would turn out to be too small to test for periods when the actual real GDP growth was more than one percentage point lower than real potential GDP growth.

${ }^{16}$ The real GDP growth rate for quarterly data was calculated as $\left(R G D P_{t}-R G D P_{t-4}\right) / R G D P_{t-4}$, where RGDP indicates quarterly real GDP and $t$ the quarter indicator. For annual data, the real GDP growth rate was calculated as $\left(R G D P_{t}-R G D P_{t-1}\right) / R G D P_{t-1}$, where RGDP indicates annual real GDP and $t$ the year indicator.
} 
bad times, as the interaction term coefficient is not significantly different from zero even at the 10 percent level. ${ }^{17}$

Table 2 reports estimation results using annual data from 1995 to 2008. Column 5 presents the estimation results for the sample of EU countries. A one percentage point increase in the output gap corresponds to an increase in VAT C-efficiency by 0.9 percentage point. Column 7 presents results for a broader set of countries, which show a somewhat larger output gap coefficient (1.17). The annual data estimation results are in line with quarterly data estimation results (Table 1), which are about one-fourth of the annual output gap coefficient. These results imply that in an average economy, if output declined from potential to 5 percent below potential, VAT C-efficiency would fall by almost 6 percentage points (from 62 to 56 percent).

Applying the interacted model as specified in columns 6 and 8, we find no evidence that the slope of VAT C-efficiency with respect to the output gap differs significantly between good and bad times, which is in line with the quarterly data estimation results shown in column 4 and discussed above.

Table 2: Estimation Results: Good, bad times, Annual Data

Dependent variable: VAT C-efficiency

\begin{tabular}{|c|c|c|c|c|}
\hline \multirow[b]{2}{*}{ VARIABLES } & \multicolumn{2}{|c|}{ EU countries $1 /$} & \multicolumn{2}{|c|}{ Broader set of countries 2/ } \\
\hline & $(5)$ & $(6)$ & (7) & $(8)$ \\
\hline \multirow[t]{2}{*}{ Gap } & $0.904 * * *$ & $0.975 * * *$ & $1.166 * * *$ & $1.290 * * *$ \\
\hline & $(0.229)$ & $(0.249)$ & $(0.193)$ & $(0.254)$ \\
\hline \multirow[t]{2}{*}{ Bad times } & & -0.907 & & -0.784 \\
\hline & & $(0.831)$ & & $(0.666)$ \\
\hline \multirow[t]{2}{*}{ Bad times*Gap } & & -0.631 & & -0.618 \\
\hline & & $(0.745)$ & & $(0.408)$ \\
\hline \multirow[t]{2}{*}{ Constant } & $67.13 * * *$ & $67.35 * * *$ & $62.13 * * *$ & $62.25 * * *$ \\
\hline & $(0.351)$ & $(0.478)$ & $(0.273)$ & $(0.390)$ \\
\hline Observations & 405 & 405 & 674 & 674 \\
\hline R-squared & 0.055 & 0.063 & 0.091 & 0.098 \\
\hline Number of countries & 32 & 32 & 84 & 84 \\
\hline
\end{tabular}

$1 /$ Countries in the sample are listed in list B in the Appendix.

2 / Countries in the sample are listed in list $\mathrm{C}$ in the Appendix.

Notes: Robust standard errors in parentheses; ${ }^{* * *} \mathrm{p}<0.01,{ }^{* *} \mathrm{p}<0.05,{ }^{*} \mathrm{p}<0.1$

We then test whether the gap coefficient differs between advanced and developing economies. ${ }^{18}$ Table 3 shows that, while the gap coefficient for advanced economies in column 9 appears

\footnotetext{
${ }^{17}$ To rule out multicollinearity between the "bad times" intercept and the "bad times" slope, we have also run this regression without the former. There was still no significant difference between good and bad times in terms of the slope.
} 
slightly lower than for developing economies in column 10, the two coefficients are not statistically different in a model where the output gap coefficient is interacted with an advanced economy dummy variable. Column 11 shows that, in developing economies, a one percentage point increase in the output gap corresponds to a 1.27 percentage point increase in VAT Cefficiency, but the statistically insignificant interaction term coefficient indicates that the link between C-efficiency and the output gap for advanced economies is not different than for developing economies.

Table 3: Estimation Results: Advanced and developing economies, Annual Data Dependent variable: VAT C-efficiency

\begin{tabular}{lllll}
\hline \hline VARIABLES & $\begin{array}{l}\text { Full sample 1/ } \\
(7)\end{array}$ & $\begin{array}{l}\text { Advanced } \\
(9)\end{array}$ & $\begin{array}{l}\text { Developing } \\
(10)\end{array}$ & $\begin{array}{l}\text { Interacted } \\
(11)\end{array}$ \\
\hline Gap & $1.166^{* * *}$ & $1.019^{* * *}$ & $1.274^{* * *}$ & $\begin{array}{l}1.274^{* * *} \\
(0.269)\end{array}$ \\
Advanced*Gap & $(0.193)$ & $(0.274)$ & $(0.277)$ & -0.254 \\
& & & & $(0.389)$ \\
Constant & $62.13^{* * *}$ & $69.26^{* * *}$ & $53.25^{* * *}$ & $62.14^{* * *}$ \\
& $(0.273)$ & $(0.338)$ & $(0.45)$ & $(0.273)$ \\
Observations & & & & \\
R-squared & 674 & 374 & 300 & 674 \\
Number of countries & 0.091 & 0.062 & 0.118 & 0.092 \\
\hline
\end{tabular}

$1 /$ Countries in the sample are listed in list $\mathrm{C}$ in the Appendix.

Notes: Robust standard errors in parentheses; ${ }^{* * *} \mathrm{p}<0.01,{ }^{* *} \mathrm{p}<0.05,{ }^{*} \mathrm{p}<0.1$

The regression results obtained so far suggest a positive and significant relationship between VAT C-efficiency and the output gap. Next, we examine variables that, in our view, could provide important channels through which the output gap variable has an impact on VAT Cefficiency.

\section{Shifts in Consumption Patterns}

Consumption patterns typically change during the business cycle. During a downturn (upswing), it is reasonable for rational consumers to increase (decrease) the share of necessity goods and services in total consumption. While data on the share of necessity goods and services in total consumption are not available for a broad set of countries, we obtained data from Eurostat on the share of food and non-alcoholic beverages in total consumption for EU countries. Using these data, we find empirical evidence of a negative correlation between the share of food and non-alcoholic beverages in total consumption and the output gap in EU countries over 1970-2008. In turn, shifts in consumption patterns can have a significant impact on revenue

\footnotetext{
${ }^{18}$ Advanced economies represent high-income countries. Developing economies represent middle- and low-income countries. The income classification is based on the World Bank's World Development Indicators.
} 
collections, as necessity items are either zero-rated or taxed at a lower than standard rate in many countries.

The importance of consumption pattern changes during the business cycle can be illustrated by the recent experience in Iceland. The VAT standard rate in Iceland was $241 / 2$ percent during 2007-08, with some goods and services subjected to rates of 0 or 7 percent. Figure 3 compares the share of consumption subjected to 0 or 7 percent rate to the share of consumption subjected to the VAT standard rate during this period. ${ }^{19}$ When the output gap dropped from $5 \frac{1}{2}$ percent above potential in 2007 to $2 \frac{1}{4}$ percent in 2008 (right-hand scale), the share of consumption of goods and services taxed at lower VAT rates increased by almost 7 percentage points, while the share of consumption of the products taxed at the VAT standard rate decreased by about $3 \frac{1}{2}$ percentage points. As a result, VAT revenue dropped even as consumption increased by more than 5 percent from 2007 to 2008.

Figure 3. Iceland. Share of Consumption and Output Gap

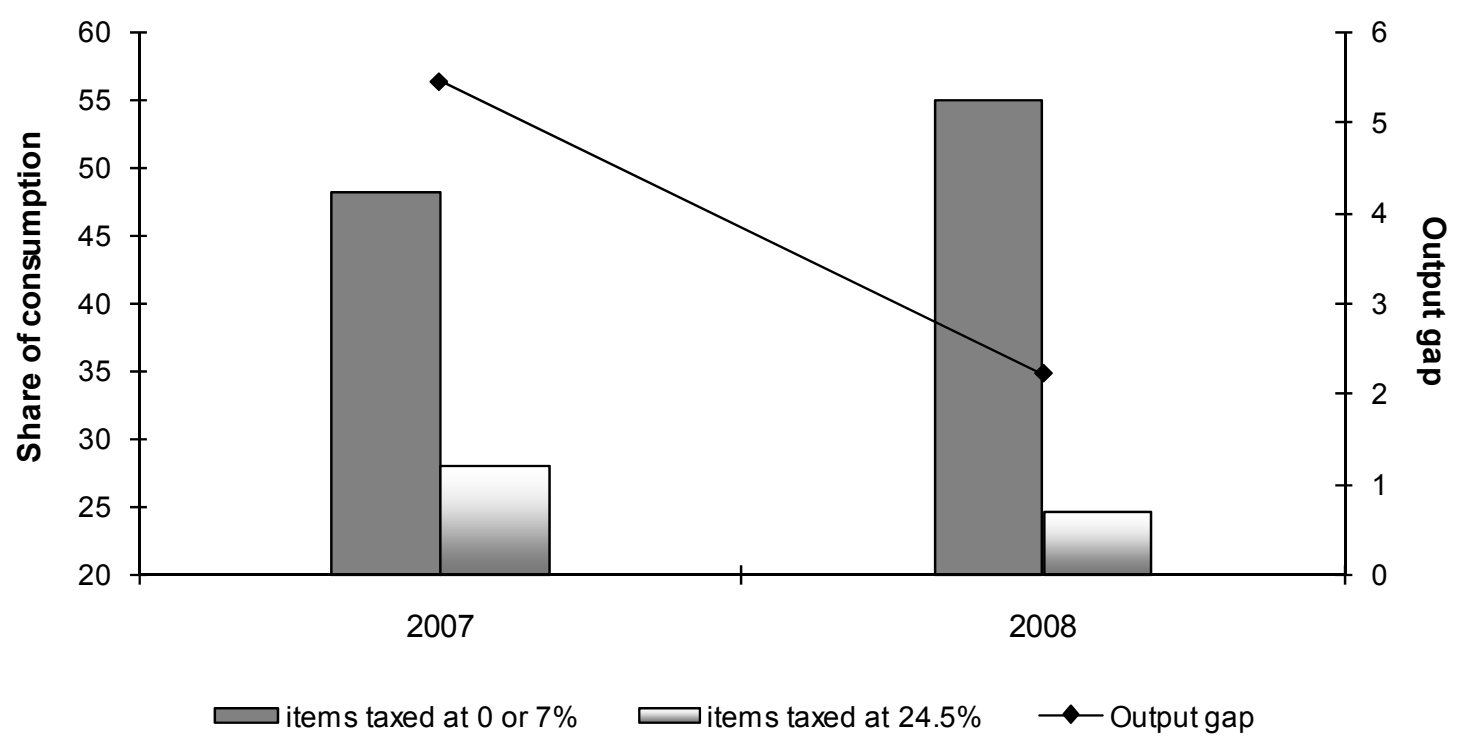

Source: Icelandic authorities.

In order to take into account shifts in consumption patterns during the business cycle, we use the share of food and non-alcoholic beverages in total consumption as a proxy for the share of necessity goods and services in total consumption. The share of food and non-alcoholic beverages in total consumption is expected to increase - and that of luxury goods is expected to

\footnotetext{
${ }^{19}$ The standard rate of $241 \frac{1}{2}$ percent included luxury or harmful goods, such as furnishings, household equipment, vehicle purchases, alcoholic beverages, and tobacco. The lower rates applied to necessity goods, such as housing rentals, water supply, transport services, and education.
} 
decrease - during a downturn; the converse would be expected during an upswing. To test this empirically, we first run the simple model for tax revenue efficiency for 25 countries (mostly in the EU) for which data on the share of food and non-alcoholic beverages in total consumption are available (column 12). The output gap coefficient is very similar to the one obtained for the whole sample of advanced economies (Table 3, column 9). When we add to the simple model for tax revenue efficiency this proxy for the share of necessity goods in total consumption, we find, as expected, that VAT C-efficiency declines as the share of necessity goods in total consumption increases (column 13). Furthermore, the output gap coefficient declines from 1.01 to 0.56 , supporting our view that the shift in consumption patterns is a key channel through which the output gap variable has an impact on VAT C-efficiency.

\section{Tax Evasion}

VAT C-efficiency can also be affected by changes in tax evasion during the business cycle given that firms and households are more likely to evade taxes when they are, for instance, credit constrained and financially distressed. In the absence of hard data on tax evasion, we rely on a qualitative indicator provided by the IMD's World Competitiveness Online. This indicator is based on IMD's company executives' surveys ${ }^{20}$ ranking tax evasion issues on a scale from zero to 10 (higher numerical values imply less severe tax evasion). An increase in the ability to control tax evasion is, therefore, expected to correspond to an increase in VAT C-efficiency.

The estimation results show that VAT C-efficiency indeed improves when tax evasion is better controlled as the coefficient on the control of tax evasion is positive (column 14). The addition of this explanatory variable to the simple model for tax revenue efficiency also reduces the coefficient of the output gap, although not as much as the addition of the share of necessity goods. When proxy variables for shifts in consumption patterns and the ability to control tax evasion are simultaneously added to the simple model for tax revenue efficiency, the estimated regression coefficients are both significant and the output gap coefficient is reduced from 1.01 to 0.56 (column 15$)$.

As discussed in the literature review section, institutions and the tax system itself can influence the behaviour of tax payers. Therefore, to test the effect of institutions on VAT C-efficiency, we add a qualitative "law and order" indicator, which assesses the strength and impartiality of the legal system and the actual observance of laws. ${ }^{21} \mathrm{~A}$ higher numerical value of this indicator means not only a better legal framework but also better law enforcement. As previous studies have suggested that the tax burden itself can affect the incentives to pay taxes, we try to incorporate this issue in the analysis by controlling for the (lagged) tax burden, defined as the tax revenue-to-GDP ratio in the previous period.

\footnotetext{
${ }^{20}$ IMD is a research center in Switzerland. The surveys are sent to senior business leaders, who are asked to evaluate current and expected competitiveness conditions in the country where they work. The 2009 survey results are reportedly based on about 4,000 responses from 57 countries.

${ }^{21}$ Data source: International Country Risk Guide (ICRG) country risk data.
} 
Column 16 presents regression results when the "law and order" and (lagged) tax burden variables are included as alternative measures of the ability to control tax evasion. Consistent with expectations, a better institutional framework is positively correlated with VAT Cefficiency, highlighting the importance of tax enforcement institutions. Also, consistent with previous studies, we find that a higher tax burden in the economy is correlated with a lower VAT C-efficiency.

Table 4: Estimation Results with Additional Explanatory Variables, Annual Data 1/

Dependent variable: VAT C-efficiency

\begin{tabular}{|c|c|c|c|c|c|}
\hline VARIABLES & $(12)$ & $(13)$ & (14) & $(15)$ & (16) \\
\hline Gap & $\begin{array}{l}1.010^{* * *} \\
(0.288)\end{array}$ & $\begin{array}{l}0.562 * * \\
(0.269)\end{array}$ & $\begin{array}{l}0.961 * * * \\
(0.281)\end{array}$ & $\begin{array}{l}0.565^{* *} \\
(0.268)\end{array}$ & $\begin{array}{l}0.629 * * \\
(0.297)\end{array}$ \\
\hline Share of necessity goods & & $\begin{array}{l}-2.654 * * * \\
(0.400)\end{array}$ & & $\begin{array}{l}-2.491 * * * \\
(0.391)\end{array}$ & $\begin{array}{l}-2.728 * * * \\
(0.391)\end{array}$ \\
\hline Control of tax evasion & & & $\begin{array}{l}1.810^{* * *} \\
(0.518)\end{array}$ & $\begin{array}{l}0.906^{* *} \\
(0.411)\end{array}$ & \\
\hline Law \& order & & & & & $\begin{array}{l}3.114 * * * \\
(0.917)\end{array}$ \\
\hline Tax burden (lag) & & & & & $\begin{array}{l}-0.8305^{* *} \\
(0.3959)\end{array}$ \\
\hline Constant & $\begin{array}{l}67.51 * * * \\
(0.329)\end{array}$ & $\begin{array}{l}105.8^{* * *} \\
(5.737)\end{array}$ & $\begin{array}{l}58.89 * * * \\
(2.531)\end{array}$ & $\begin{array}{l}99.17 * * * \\
(6.321)\end{array}$ & $\begin{array}{l}113.1 * * * \\
(12.74)\end{array}$ \\
\hline Observations & 251 & 251 & 251 & 251 & 251 \\
\hline R-squared & 0.077 & 0.287 & 0.125 & 0.298 & 0.329 \\
\hline Number of countries & 25 & 25 & 25 & 25 & 25 \\
\hline
\end{tabular}

$1 /$ Countries are listed in list $\mathrm{D}$ in the Appendix.

Notes: Robust standard errors in parentheses; ${ }^{* * *} \mathrm{p}<0.01,{ }^{* *} \mathrm{p}<0.05,{ }^{*} \mathrm{p}<0.1$

\section{ESTIMATION RESULTS FOR PIT AND SSC EFFICIENCY}

Measuring the efficiency of other major taxes, such as the PIT and SSC, is more difficult for a number of reasons: data on the PIT and SSC base, namely wages and salaries, are not readily available, especially for developing economies; unlike the VAT system, where many goods and services are subjected to a single, standard rate, the PIT and SSC usually have multiple tax brackets; and relatedly, a zero-rated income tax bracket and basic allowance would imply different unweighted average tax rates even though they may lead to the same level of tax collection.

While we have been able to obtain consistent annual data on wages and salaries for most EU countries, we have been constrained to using the unweighted average PIT and SSC rates for different income levels when calculating the corresponding revenue efficiency. Estimation 
results applying the model for tax revenue efficiency are reported in Table 5. As shown in columns 17 and 18, PIT and SSC efficiency are both positively correlated with the output gap. ${ }^{22}$

Table 5: Estimation Results: Annual Data

Dependent variables: PIT and SSC efficiency

\begin{tabular}{lll}
\hline \hline & PIT 1/ & SSC 2/ \\
VARIABLES & $(17)$ & $(18)$ \\
\hline \multirow{2}{*}{ Gap } & & \\
& $1.428^{*}$ & $1.133^{* *}$ \\
Constant & $(0.822)$ & $(0.572)$ \\
& $56.20^{* * *}$ & $74.21^{* * *}$ \\
Observations & $(0.830)$ & $(0.627)$ \\
R-squared & 157 & 258 \\
Number of countries & 0.038 & 0.019 \\
\hline
\end{tabular}

$1 /$ Countries in the sample are listed in list $\mathrm{E}$ in the Appendix.

2/ Countries in the sample are listed in list $\mathrm{F}$ in the Appendix.

Notes: Robust standard errors in parentheses; $* * * \mathrm{p}<0.01,{ }^{*} \mathrm{p}<0.05,{ }^{*} \mathrm{p}<0.1$

\section{ESTIMATION RESULTS FOR VAT REVENUE ELASTICITY}

In this section, we report results on the more traditional VAT revenue elasticity with respect to private consumption, using the model for tax revenue elasticity described by equation (3). ${ }^{23}$ Column 19 in Table 6 shows that this elasticity is estimated at 1.1, implying that the effect of a one percent increase in consumption is a 1.1 percent increase in VAT revenue collections. However, the significance of the output gap coefficient indicates that, to project VAT revenue collections properly, one should take into account not only changes in consumption and in the VAT rate, but also changes in the output gap. The effect of a one percentage point increase in the output gap is a $13 / 4$ percent increase in VAT revenue over a year. ${ }^{24}$ As expected, the estimated output gap coefficient from equation (3) is consistent with that from equation (1), as equation (3) is simply a reformulation of equation (1). ${ }^{25}$

\footnotetext{
${ }^{22}$ Using the interacted model, the output gap remains a significant explanatory variable for SSC efficiency, but there is no statistically significant difference (in the level and slope) between good and bad times. We fail to establish any significant correlation between PIT efficiency and the output gap in the interacted model.

${ }^{23}$ The model controls for changes in tax rates but does not control for changes in other tax policy parameters.

${ }^{24}$ As the dependent variable is in log and the gap variable is not, the coefficient on the gap variable needs to be multiplied by 100 in the interpretation of results.

${ }^{25}$ As discussed earlier, the effect of a one percentage point increase in the output gap is a $1 \frac{1 / 4}{4}$ percentage point increase in VAT C-efficiency (Table 3, column 7). This result translates into a 13/4 percent change in VAT revenue using average VAT C-efficiency along trend growth (i.e., the constant term in column 7).
} 
Column 22 presents a model where all explanatory variables have been interacted with an advanced economy dummy to test if there is a significant difference in the coefficients between advanced and developing economies. Apart from the interaction term for the VAT rate, the other interaction terms are not significant, implying that there is no significant difference.

Table 6: Estimation Results: VAT Revenue Elasticity, Annual Data

Dependent variable: Log of VAT revenue

\begin{tabular}{|c|c|c|c|c|}
\hline VARIABLES & $\begin{array}{l}\text { Full sample 1/ } \\
\text { (19) }\end{array}$ & $\begin{array}{l}\text { Advanced } \\
(20)\end{array}$ & $\begin{array}{l}\text { Developing } \\
(21)\end{array}$ & $\begin{array}{l}\text { Interacted } \\
(22)\end{array}$ \\
\hline Consumption (in logs) & $\begin{array}{l}1.073 * * * \\
(0.0264)\end{array}$ & $\begin{array}{l}1.103 * * * \\
(0.0330)\end{array}$ & $\begin{array}{l}1.041 * * * \\
(0.0361)\end{array}$ & $\begin{array}{l}1.041 * * * \\
(0.0350)\end{array}$ \\
\hline Advanced*consumption & & & & $\begin{array}{l}0.0624 \\
(0.0487)\end{array}$ \\
\hline VAT rate & $\begin{array}{l}0.0288 * * * \\
(0.00806)\end{array}$ & $\begin{array}{l}0.0438 * * * \\
(0.00780)\end{array}$ & $\begin{array}{l}-0.0334 * * \\
(0.0157)\end{array}$ & $\begin{array}{l}-0.0334 * * \\
(0.0152)\end{array}$ \\
\hline Advanced*VAT rate & & & & $\begin{array}{l}0.0772 * * * \\
(0.0172)\end{array}$ \\
\hline Gap & $\begin{array}{l}0.0175^{* * *} \\
(0.00337)\end{array}$ & $\begin{array}{l}0.0112 * * * \\
(0.00410)\end{array}$ & $\begin{array}{l}0.0216^{* * *} \\
(0.00505)\end{array}$ & $\begin{array}{l}0.0216^{* * *} \\
(0.00490)\end{array}$ \\
\hline Advanced*gap & & & & $\begin{array}{l}-0.0104 \\
(0.00645)\end{array}$ \\
\hline Constant & $\begin{array}{l}-3.647 * * * \\
(0.366)\end{array}$ & $\begin{array}{l}-4.128 * * * \\
(0.435)\end{array}$ & $\begin{array}{l}-2.347 * * * \\
(0.538)\end{array}$ & $\begin{array}{l}-3.335 * * * \\
(0.339)\end{array}$ \\
\hline Observations & 674 & 374 & 300 & 674 \\
\hline R-squared & 0.862 & 0.914 & 0.838 & 0.869 \\
\hline Number of countries & 84 & 31 & 53 & 84 \\
\hline
\end{tabular}

$1 /$ Countries in the sample are listed in list $\mathrm{C}$ in the Appendix.

2/ Robust standard errors in parentheses; ${ }^{* * *} \mathrm{p}<0.01,{ }^{* *} \mathrm{p}<0.05,{ }^{*} \mathrm{p}<0.1$

Finally, Table 7 provides an illustrative summary of the implications of the main results of this paper. The column for all countries shows that a one percentage point increase in the output gap corresponds to $13 / 4$ percent increase in VAT revenue collections over a year or, equivalently, to a $1 \frac{1}{4}$ percentage point increase in VAT C-efficiency. Since models (1) and (3) are linear in the output gap, an increase in the output gap by five percentage points would correspond to five times the coefficient of the output gap, $83 / 4$ percent and $53 / 4$ percentage points, respectively. The table also presents the estimated coefficients for advanced and developing economies. However, as discussed in previous sections, those coefficients are not statistically different from each other. 
Table 7: Illustrative Summary

\begin{tabular}{|c|c|c|c|}
\hline $\begin{array}{c}\text { Change in the Output Gap 1/ } \\
\text { (percentage points) }\end{array}$ & $\begin{array}{c}\text { All } \\
\text { Countries }\end{array}$ & $\begin{array}{l}\text { Advanced } \\
\text { Economies }\end{array}$ & $\begin{array}{l}\text { Developing } \\
\text { Economies }\end{array}$ \\
\hline & \multicolumn{3}{|c|}{ Change in VAT revenues (percent) } \\
\hline 1 & 1.75 & 1.12 & 2.16 \\
\hline \multirow[t]{2}{*}{5} & 8.75 & 5.6 & 10.8 \\
\hline & \multicolumn{3}{|c|}{ Change in VAT C-efficiency (percentage point) } \\
\hline 1 & 1.17 & 1.02 & 1.27 \\
\hline 5 & 5.83 & 5.10 & 6.37 \\
\hline
\end{tabular}

\section{COnCLuding Remarks}

This paper aimed to fill a gap in the literature by estimating, for a broad set of advanced and developing economies, the relationship between tax revenue efficiency and the output gap. We focused our efforts primarily on the response of VAT C-efficiency as we have been able to piece together a consistent and detailed database for this important tax. However, we found consistent results also for the responses of PIT and SSC efficiency.

We estimate that a one percentage point increase in the output gap corresponds to $1 \frac{1}{4}$ percentage point increase in VAT C-efficiency or, equivalently, to $13 / 4$ percent increase in VAT revenue collections. These results are consistent for quarterly and annual data, across advanced and developing economies, and in both good and bad times (defined on the basis of the growth rate of output).

We also find that shifts in consumption patterns toward goods and services with lower (higher) VAT rates and higher (lower) tax evasion during economic contractions (expansions) are key channels through which the output gap affects VAT C-efficiency. During contractions (expansions), households consume a higher (lower) share of their income on necessity goods and services, which in many countries are either not taxed or taxed at a lower than the VAT standard rate. A closer examination of the determinants of tax evasion reveals that VAT C-efficiency is positively correlated with stronger institutional underpinnings of the revenue administration and negatively correlated with the overall tax burden in the economy.

A key implication of our paper is that — particularly during major economic booms and sharp economic downturns - policymakers should be encouraged to look beyond long-run revenue elasticities and incorporate into their analysis the effects of the economic cycle on tax revenue efficiency. In turn, improvements in revenue forecasting during the business cycle would 
enhance the calculation of structural fiscal balances and, hence, it would help shed light on the need for, and effectiveness of, counter-cyclical fiscal policy. 


\section{Appendix: List of countries}

\section{List A: Quarterly data}

Austria, Belarus, Belgium, Brazil, Bulgaria, Czech Republic, Denmark, Egypt, Estonia, Finland, France, Germany, Greece, Hungary, Iceland, Indonesia, Ireland, Italy, Latvia, Lithuania, Luxembourg, Malta, Mexico, Netherlands, Peru, Philippines, Poland, Portugal, Romania, Slovak Republic, Slovenia, Spain, Sweden, Turkey, Ukraine, and the United Kingdom.

\section{List B: Annual data for EU countries}

Austria, Belgium, Bulgaria, Croatia, Cyprus, Czech Republic, Denmark, Estonia, Finland, France, Germany, Greece, Hungary, Ireland, Italy, Latvia, Lithuania, Luxembourg, Malta,

Netherlands, Norway, Poland, Portugal, Romania, Slovak Republic, Slovenia, Spain, Sweden, Switzerland, Turkey, Ukraine, and the United Kingdom.

\section{List C: Annual data for a broader set of countries including EU countries}

Albania, Argentina, Armenia, Australia, Austria, Bangladesh, Barbados, Belarus, Belgium, Bolivia, Brazil, Bulgaria, Cambodia, Canada, Cape Verde, Chad, Chile, Colombia, Congo, Republic of Croatia, Cyprus, Czech Republic, Côte d'Ivoire, Denmark, Dominican Republic, Egypt, El Salvador, Estonia, Finland, France, Gabon, Georgia, Germany, Greece, Honduras, Hungary, Indonesia, Ireland, Israel, Italy, Jamaica, Kazakhstan, Korea, Kyrgyz Republic, Latvia, Lesotho, Lithuania, Luxembourg, Madagascar, Malta, Moldova, Mongolia, Morocco, Nepal, Netherlands, New Zealand, Nigeria, Norway, Pakistan, Paraguay, Peru, Philippines, Poland, Portugal, Romania, Russia, Senegal, Serbia, Republic of, Slovak Republic, Slovenia, South Africa, Spain, Sweden, Switzerland, Tajikistan, Tanzania, Trinidad and Tobago, Turkey, Uganda, Ukraine, the United Kingdom, Uruguay, Vietnam, and Zambia.

\section{List D: Countries with data for the share of necessity goods and control of tax evasion}

Austria, Belgium, Czech Republic, Denmark, Estonia, Finland, France, Germany, Greece, Hungary, Ireland, Italy, Lithuania, Luxembourg, Netherlands, Norway, Poland, Portugal, Romania, Slovak Republic, Slovenia, Spain, Sweden, Switzerland, and the United Kingdom.

\section{List E: Subsample of EU countries with PIT data}

Austria, Belgium, Czech Republic, France, Greece, Ireland, Italy, Luxembourg, Netherlands, Poland, Portugal, Slovak Republic, and the United Kingdom.

\section{List F: Subsample of EU countries with SSC data}

Austria, Belgium, Czech Republic, Denmark, Finland, France, Germany, Greece, Hungary, Ireland, Italy, Luxembourg, Netherlands, Norway, Poland, Portugal, Spain, Sweden, Switzerland, and the United Kingdom. 


\section{References}

Agha, Ali, and Jonathan Haughton, 1996, "Designing VAT Systems: Some Efficiency Considerations," Review of Economics and Statistics, Vol. 78, No. 3, pp. 303-08.

Aizenman, Joshua, and Yothin Jinjarak, 2008, "The Collection Efficiency of the Value Added Tax: Theory and International Evidence," The Journal of International Trade \& Economic Development, Vol. 17, No. 3, pp. 391-410.

Brondolo, John, 2009, Collecting Taxes during an Economic Crisis: Challenges and Policy Options, IMF Staff Position Note, SPN/09/17 (Washington: International Monetary Fund).

Cai, Hongbin, and Qiao Liu, 2009, "Competition and Corporate Tax Avoidance: Evidence from Chinese Industrial Firms,” The Economic Journal, Vol. 119, Issue 537, pp. 764-95.

De Mello, Luiz, 2009, "Avoiding the Value-added Tax: Theory and Cross-country Evidence," Public Finance Review, Vol. 37, No. 1, pp. 27-46.

Eble, Stephanie, Cemile Sancak, and Ricardo Velloso, 2009, "Revenue Forecasting in Crisis Countries: Preliminary Lessons from Six Program Countries," FAD, IMF, mimeo.

Ebrill, Liam, Michael Keen, Jean-Paul Bodin, and Victoria Summers, 2001, The Modern VAT (Washington: International Monetary Fund).

Plumley, Alan H., 1996, “The Determinants of Individual Income Tax Compliance: Estimating the Impacts of Tax Policy, Enforcement, and IRS Responsiveness," Department of the Treasury, Internal Revenue Service, Publication 1916 (Rev. 11-96). 